\title{
CONTRIBUTION OF GEOPHYSICAL METHODS TO THE INVESTIGATION OF GEOTHERMAL CONDITIONS IN THE SOUTHWESTERN PART OF THE STRYMON BASIN (MACEDONIA, NORTHERN GREECE)
}

\author{
Arvanitis A.A. ${ }^{1}$, Stampolidis A.D. ${ }^{2}$, and Tsokas G.N. ${ }^{2}$ \\ ${ }^{1}$ Institute of Geology and Mineral Exploration, Division of Geothermal Energy and Thermal Mineral Wa- \\ ters, Entrance C, Olympic Village, 13677, Acharnae, Attica, Greece, arvanitis@igme.gr \\ ${ }^{2}$ Department of Geophysics, School of Geology, Aristotle University of Thessaloniki, 54124, \\ Thessaloniki, Greece, \\ astamp@geo.auth.gr,gtsokas@geo.auth.gr
}

\begin{abstract}
The Strymon basin is one of the most important sedimentary basins in Northern Greece where significant geothermal fields are located. The SW part of the Strymon basin manifests geothermal interest. Available geophysical data (seismic, gravity, magnetic and electrical data) contributed to the identification of major faults that control the fluid-flow paths of the geothermal field and the estimation of depth to the metamorphic basement. The former is of great importance because the geothermal aquifer is expected to be at the contact of the basal conglomerate with the metamorphic basement. The highest thermal gradient values $\left(10-15^{\circ} \mathrm{C} / 100 \mathrm{~m}\right)$ were observed in the western part of the study area near the known geothermal field of Therma - Nigrita. Other important geothermal anomalies $\left(>6^{\circ} \mathrm{C} / 100 \mathrm{~m}\right)$ occur in the Patriki area, north of the village of Ivira and in the area between the villages of Patriki and Achinos. Geothermal interest manifests itself in the following areas: north of Mavrothalassa $\left(>4^{\circ} \mathrm{C} / 100 \mathrm{~m}\right)$, southwest of Ivira and east of Agios Dimitrios. It appears furthermore that the main thermal anomaly is associated with two NW-SE fault systems that affect the basement in the areas of Patriki and north of Achinos - Ivira correspondingly. These faults have been detected by the use of geophysical surveys. The presence of NE-SW faults extends the anomaly southwestwards.
\end{abstract}

Key words: Strymon basin, geothermal fields, Ivira, Achinos, geophysical methods, Serres.

\section{Introduction}

The Strymon basin is a typical post-orogenic graben. It has been formed between the Serbomacedonian Massif (SMM) to the Rhodope massif to the east. The eastern margins of the basin belong to the Pangeon Unit of the Rhodope massif composed of marbles, gneisses and mica schists. The Vrondou granitic complex intrudes the metamorphic rocks of the Pangeon Unit. The Serbomacedonian massif is divided into two crystalline 'series': (a) the Kerdylia Series (at the SW margins of the basin) composed of migmatic gneisses, amphibolies and marbles and (b) the Vertiskos Series made up of intercalations of schists, leucocratic and augen gneisses and amphibolites. Late Paleozoic, Cretaceous and Paleogene granitoid bodies intruded into the Serbomacedonian massif. The 
total thickness of Neogene and Quaternary sediments at the center of the basin is approximately $4000 \mathrm{~m}$. The principal faults are oriented in NW-SE, NNE-SSW to NE-SW and WNW-WSE to WE directions. The Strymon basin is of primary geothermal interest. Some important low enthalpy geothermal fields exist. The Therma - Nigrita, Sidirokastro, Lithotopos - Iraklia and Agistro fields have already been characterized officially as 'proven' and/or 'probable low temperature geothermal fields' with water temperatures between 40 and $74^{\circ} \mathrm{C}$. The geothermal aquifers are located at relatively shallow depths $(30-500 \mathrm{~m})$. The geothermal anomaly occurs mainly due to deep fault systems being normal and strike-slip structures. In the central part of the Strymon basin of the Strymon basin three deep exploration oil boreholes (STR-1, STR-2, STR-3 at depths of 3651, 2678 and 3144 $m$ respectively) were drilled. In borehole STR-1 the average geothermal gradient is $31^{\circ} \mathrm{C} / \mathrm{km}$ and the temperatures of $57,66,106$ and $135^{\circ} \mathrm{C}$ were measured at depths of $1209,1475,2884$ and $3651 \mathrm{~m}$ correspondingly. The geothermal gradient for the Strymon basin has been estimated to fluctuate from 25 to $36^{\circ} \mathrm{C} / \mathrm{km}$ at depths of more than $2000 \mathrm{~m}$ (P.P.C., 1988). The geothermal conditions in the Strymon basin are favourable as a result of the active extension tectonics and the increased heat flow. Tertiary granitoids of Vrondou and Pangeon increased the regional heat flow. Additionally, the large deep and open faults of the basin are favourable for the uprising of the geothermal fluids at relatively shallow and exploitable depths or at surface. The general geological settings favour the formation of a geothermal field including: (a) the existence of conglomerates and breccias on the top of the basement and as interbedded strata, (b) the presence of an impermeable cap consisting of Neogene clayey and marly sediments and (c) the water circulation into the permeable sediments and the fractured crystalline rocks supplying continually the reservoir (Arvanitis, 2003).

A new very interesting geothermal area has been recently explored in the southwestern part of the Strymom basin. This area extends from the villages of Choumniko and Patriki in the west to the villages of Efkarpia and Tragilos in the east (Fig. 1) covering an area of about $25 \mathrm{~km}^{2}$. It was explored by the Aristotle University of Thessaloniki (School of Geology) and I.G.M.E. during 1993-2002. The preliminary geothermal investigation was performed mainly by the Aristotle University (Arvanitis, 2003) and included geological and tectonic study of the area, interpretation of available geophysical data (seismic, gravity, magnetic and geoelectrical data), a detailed thermometric survey with water temperature measurements of existing water supply and irrigation wells, water sampling and chemical analyses, hydrochemical study etc. This paper presents the results of the interpretation of available geophysical data that contributed to the identification of major faults controlling the fluidflow paths of the geothermal field and the estimation of depth to the metamorphic basement.

\section{Geological and tectonic setting}

Geologically the southwestern part of the Strymon basin belongs to the Serbomacedonian massif. The crystalline basement is composed of mica schists, biotite gneisses, amphibolitic gneisses, marbles, plagioclase gneisses, pegmatites, quartzites, etc. Neogene and Quaternary sediments have been deposited over the basement rocks (Fig. 1). These sediments consist of the basal conglomerates, limestones, sandy limestones, sandstones, sands, marls, sandy marls, marly limestones, silts, clays, sandy clays with interbedded strata of gravels and cobbles. The main characteristic of these deposits is their clayey-marly composition and therefore they can form an impervious cap for the geothermal fluids. In these sediments there are shallow aquifers containing waters at temperatures of 25$35^{\circ} \mathrm{C}$ and deeper aquifers bearing higher temperature waters $\left(50-60^{\circ} \mathrm{C}\right)$. The total thickness of the Neogene and Quaternary sediments ranges from a few meters (close to the basement) to $1000 \mathrm{~m}$ (north of the villages of Achinos and Ivira) or more reaching up to $4 \mathrm{~km}$ in the central part of the Strymon basin (Arvanitis, 2003). 


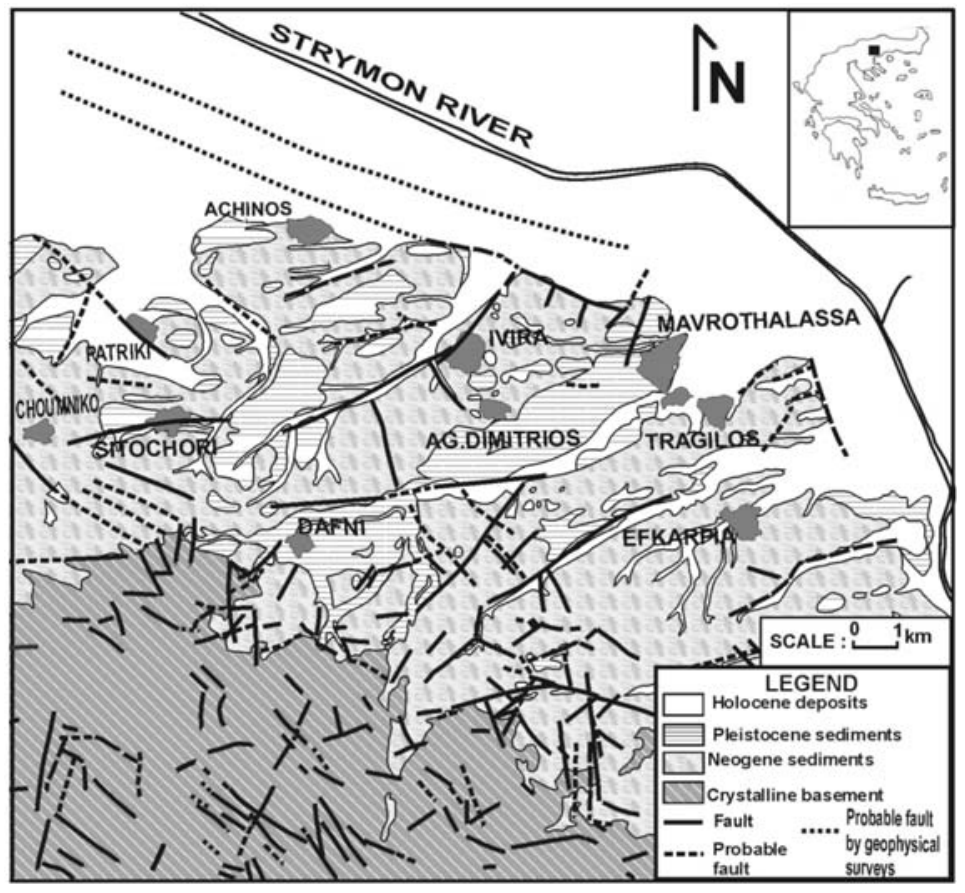

Fig. 1: Simplified geological map of the southwestern part of the Strymon basin (Arvanitis, 2003).

The tectonic setting in the area is very complicated. The faults are oriented in NE-SW, NW-SE and E-W directions affecting the crystalline basement and the overlying sediments. The gradual tectonic subsidence of the basement from south to north is characteristic. Fig. 1 is a simplified geological map showing the faults in the southwestern part of the Strymon basin. The interpretation of available geophysical (seismic, geoelectrical, gravimetric) surveys has revealed the presence of large faults covered by sediments.

\section{Geophysical Methods}

\subsection{Seismic methods}

In the Strymon basin, seismic surveys conducted by Public Petroleum Corporation (P.P.C.) during 1977-1979. A total of 11 seismic reflection lines (12-18 km long) were measured by P.P.C. and processed by BEICIP-FRANCE in 1980 (P.P.C. Strymon Report, personal communication). Interpretation results from 4 seismic reflection lines namely LINE-7, LINE-99 and LINE-13 of the P.P.C. surveys were used in this study to define the geological and tectonic setting of the geothermal area in the SW part of the Strymon basin. The numbers along the seismic profiles constitute the C.D.P. (Common Depth Point) positions. In multichannel reflection profiling, C.D.P. is the unique point on an individual reflector from which seismic reflection information is recorded in traces at different offsets. The traces are sorted by computer into gathers with the same C.D.P. The C.D.P. method is a seismic data acquisition and processing technique which transforms field recordings from seismic surveys into pseudo-cross-sectional images of the earth's geologic layering beneath the survey line. Velocity analysis, gathering, stacking and migration are routinely applied to the 'raw' data. The C.D.P. method helps the migration and stacking processes. Deep exploration oil borehole STR-1 is 


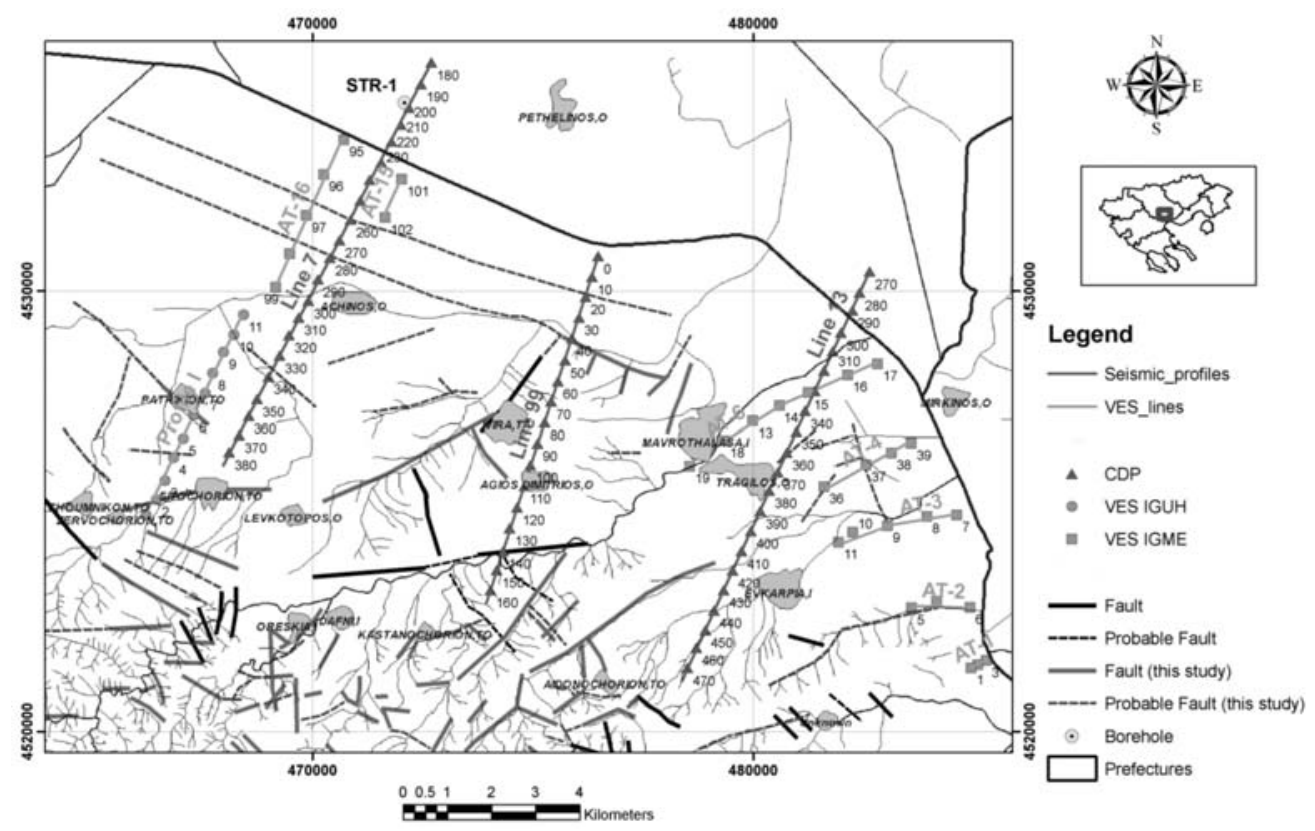

Fig. 2: Location map of the southwestern part of the Strymon basin illustrating the positions of the seismic lines LINE 7, LINE 99 and LINE 13 and the VES profiles from University of Hamburg (IGUM) and IGME.

located next to C.D.P. 200 on the seismic Line 7 (Fig. 2). The lithology column of this well consists of Pleistocene deposits (0-870 m depth), Pliocene sediments (870-1711 m) and Miocene formations (1711-3651 m). The basement was penetrated at a depth of $3651 \mathrm{~m}$. Correlation between seismic records and borehole geological data was performed. Pleistocene deposits Vp velocity values range between 1.9 and $2.2 \mathrm{~km} / \mathrm{sec}$, Pliocene sediments between 2.9 and $4.0 \mathrm{~km} / \mathrm{sec}$, while Miocene sediments shown slightly higher velocities from the overlain ranging between 3.0 and $4.18 \mathrm{~km} / \mathrm{sec}$. The $\mathrm{Vp}$ velocity of the basement was calculated about $5.0 \mathrm{~km} / \mathrm{sec}$. The suggestions for the Vp velocity values and the results of the seismic profile 'Line-7' were confirmed by some wells. For example, near CDP 380, a well, $210 \mathrm{~m}$ deep, has penetrated gravels and pebbles probably belonging to basal conglomerate at the bottom. This means that the basement is expected to be a few meters deeper than $210 \mathrm{~m}$. Based on the data from seismic profile 'Line-7' the basement depth is estimated to be about $239 \mathrm{~m}$ indicating a very good correlation between the seismic data and the well data.

The seismic surveys can considerably aid the structural investigation in the SW part of the Strymon basin. All the above-mentioned seismic profiles show a general northward dip of the basement towards the basin centre. The total thickness of sediments exceeds $3.5 \mathrm{~km}$ in the basin centre. Miocene sediments show a significant increase in thickness $(650-1600 \mathrm{~m})$ in the central part of the basin. The thickness of Pliocene sediments ranges from $180 \mathrm{~m}$ at the margins to $1000 \mathrm{~m}$ in the area of the Strymon River. There is similarly a gradual increase in thickness of Pleistocene deposits ranging from $200 \mathrm{~m}$ at the margins to $550-850 \mathrm{~m}$ in the centre of the basin. Seismic reflection data have been used to provide information on the tectonic setting of the study area. Normal faults have been identified resulting in the deepening of the basement. The location of a major normal NW-SE trending fault along the southwestern margin of the basin has been traced north of the villages of Achinos, Ivira and Mavrothalassa and south of the Strymon River. This fault (or probably fault zone) is responsi- 


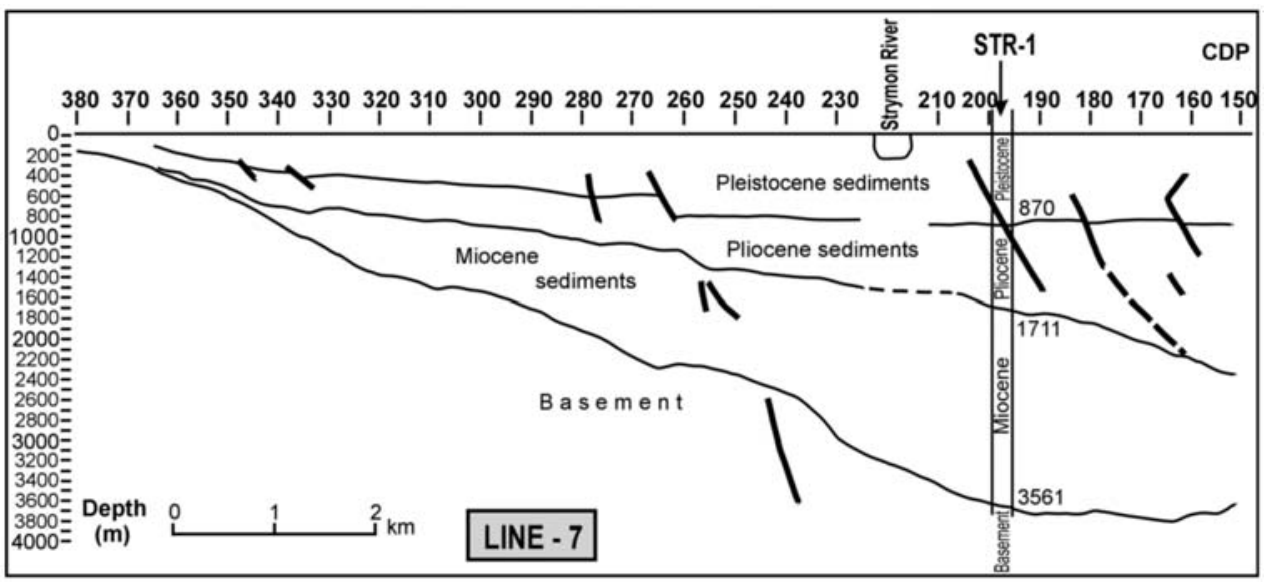

Fig. 3: Interpreted profile of seismic Line-7.

ble for the large-scale and abrupt deepening of the basement. The presence of a tectonic terrace system in the area confirms the results of the seismic reflection surveys. The interpretation of these seismic reflection data allowed the correlation between other terraces and faults or fault systems of a minor geothermal interest in the study area.

Seismic profile Line-7 indicates the existence of faults between CDP 270 and 250 (Fig. 3). These faults have influenced Pleistocene deposits, Pliocene sediments and Miocene formations as well as the basement of the basin. All these faults can be considered as a fault zone affecting the basement and the overlying sedimentary sequence and the basin deepens northwards. This fault zone is located at a small distance (about $1 \mathrm{~km}$ ) north of the probable structural terrace extended between the area of the village of Achinos and north of Mavrothalassa (Fig. 1,2). Another fault is noted on profile Line-7 at CDP 280 affecting Pleistocene and Pliocene sediments. This fault may be related to the above-mentioned fault zone. The location of this fault coincides with the pre-mentioned terrace. Other two small faults are recognized between CDP 350 and 330 located southwest of the village of Achinos. The total thickness of Neogene and Quaternary sediments increases from the margins towards the central part of the basin and the basement deepens from $161 \mathrm{~m}$ at CDP 380 to $3100 \mathrm{~m}$ below sea level (bsl) in the area of the Strymon River. In the area of the village of Achinos the basement depth is estimated to be about $1550 \mathrm{~m}$ bsl.

The first interpretation of seismic profile Line-99 (Fig. 4) shows a large normal fault between CDP 50 and 40 . This fault affects the basement and the basement abruptly deepens northwards from 1305 $\mathrm{m}$ to $1830 \mathrm{~m}$ bsl. The thickness of Miocene sediments increases from $430 \mathrm{~m}$ to $950 \mathrm{~m}$. This fault is located at about $2 \mathrm{~km}$ north of Ivira and coincides with the above-mentioned terrace of Achinos Mavrothalassa. The small faults observed between CDP 50 and 20 affecting Pleistocene and Pliocene sediments may be associated with the large-scale basement fault. Two normal faults are recognized between CDP 120 and 100 on this seismic profile. The second fault detected between CDP 110 and 100 displays antithetic dip. These faults are located in the area of the village of Agios Dimitrios. Pleistocene deposits increase in thickness from $210 \mathrm{~m} \mathrm{SW}$ of the village of Ag. Dimitrios to $550 \mathrm{~m}$ at CDP 0 . The thickness of Pliocene sediments increases gradually from $420 \mathrm{~m} \mathrm{SW}$ of Ag. Dimitrios to about $960 \mathrm{~m}$ at CDP 20. An abrupt increase in thickness of these sediments is observed between CDP 20 and the Strymon River bed. Miocene sediments have a significant thickness (about $950 \mathrm{~m}$ ) 


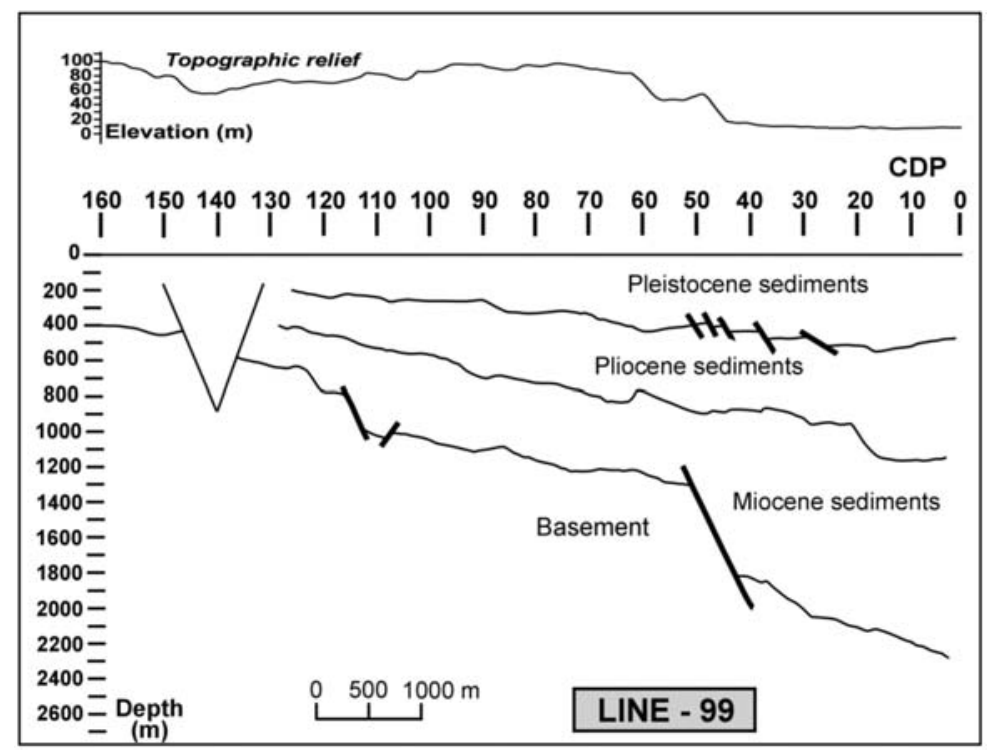

Fig. 4: Interpreted profile of seismic Line-99 (first interpretation).

at CDP 40 reaching $1140 \mathrm{~m}$. In the area of the villages of Ivira and Agios Dimitrios and southwest of CDP 40, Miocene sediments have a thickness of 400-460 m, decreasing to 220-320 m southwest of the village of Ag. Dimitrios.

The second interpretation of seismic profile Line-99 (Fig. 5) shows a probable normal fault between CDP 60 and 50 affecting Pleistocene and Pliocene sediments. The downward extension of this fault indicates a northward dip of the basement due to the action of a large normal basement fault. The main characteristic of this profile is the basement uplift between CDP 80 and 50. This uplift is located north and northeast of the village of Ivira and coincides with a relatively small increase in topographic relief of this area (Fig. 4). Two faults have been identified between CDP 40 and 20 affecting Pleistocene and Pliocene deposits. Another normal fault has been detected at CDP 100 close to the village of Agios Dimitrios. This fault with throw of about $108 \mathrm{~m}$ seems to deepen the basement and the thickness of Miocene sediments increases. Miocene sediments show a considerable thinning southwest of CDP 100 and they are wedged at CDP 130. Their thickness ranges from 600 to $800 \mathrm{~m}$ between the villages of Agios Dimitrios and Ivira. A decrease in their thickness is observed in the area between the village of Ivira and the Lochagos Height where basement uplift is also observed and then the thickness increases up to $834 \mathrm{~m}$ in the Strymon River bed. Pliocene sediments increase in thickness from $520 \mathrm{~m}$ at CDP 130 to $1030 \mathrm{~m}$ at CDP 0 with a value of $840 \mathrm{~m}$ at CDP 80 . The thickness of Pleistocene deposits remains almost constant (230-299 m) between CDP 130 and 70 and then it increases significantly towards the Strymon River bed, reaching $580 \mathrm{~m}$.

Seismic profile Line-13 shows a group of 7 normal faults between CDP 370 and 300 located northeast and north of the village of Tragilos (Fig. 6). These successive faults have affected Pleistocene and Pliocene sediments. The continuous deepening of the basement between CDP 370 and 300 indicates that these faults are probably extended to greater depths affecting the basement. In this area, Miocene formations increase in thickness significantly. Therefore, the group of 7 faults is likely associated with a large-scale fault zone. The basement deepens gradually from 760 to $1200 \mathrm{~m}$ between the villages of Efkarpia and Tragilos along this line. There, the thicknesses of Neogene and Qua- 


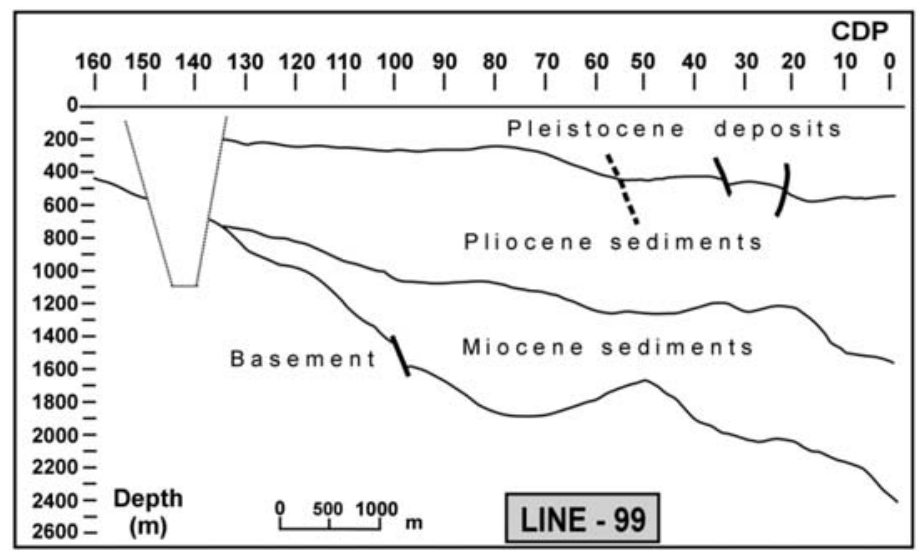

Fig. 5: Interpreted profile of seismic Line-99 (second interpretation).

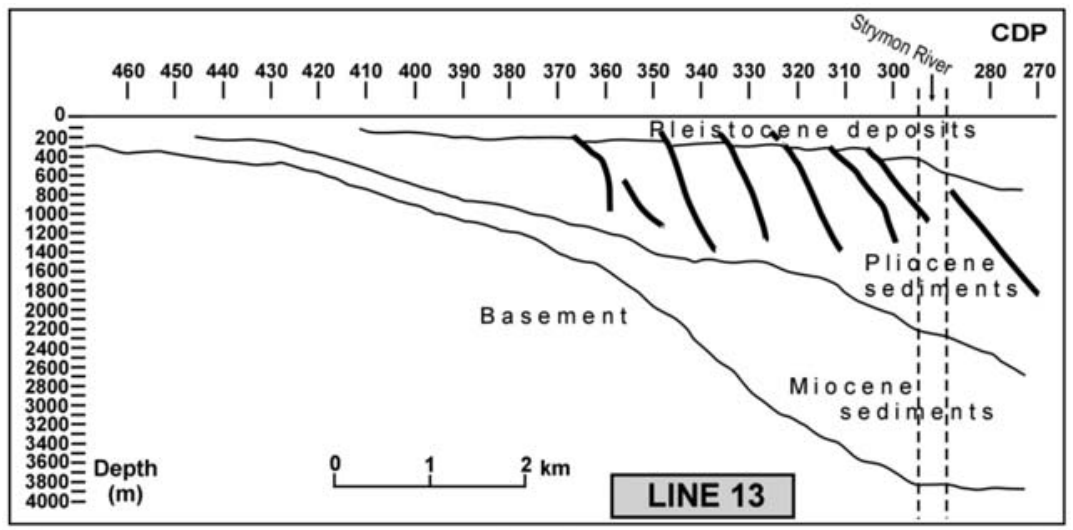

Fig. 6: Interpreted profile of seismic Line-13.

ternary sediments vary from 150 to $230 \mathrm{~m}$ for Pleistocene deposits, from 380 to $700 \mathrm{~m}$ for Pliocene sediments and from 230 to $265 \mathrm{~m}$ for Miocene formations. A significant increase in thickness of Miocene sediments is observed northeast of CDP 370 towards the Strymon River bed reaching 1648 $\mathrm{m}$ there. Miocene sediments have a thickness of the order of $200 \mathrm{~m}$ west of the village of Efkarpia.

\subsection{Geoelectrical methods}

Geoelectrical surveys were carried out mainly by the Institute of Geophysics of the University of Hamburg (P.P.C., 1981) and the Institute of Geology and Mineral Exploration (I.G.M.E.) in order to investigate the local geological and tectonic conditions studying the spatial distribution of the resistivity values in the subsurface and detecting faults that affect the sediments and probably penetrate the underlying basement. The locations of these geoelectrical surveys are shown in Fig.2.

Deep geoelectrical surveys (exploration depth $>500 \mathrm{~m}$ ) were carried out at various places in the Strymon basin by the Institute of Geophysics of the University of Hamburg (Prof. J. Makris) in the frame of a project called 'Geothermal Energy Project - Serres basin area - Geoelectrical survey' and financed by Public Power Corporation (P.P.C.) of Greece (P.P.C., 1981). Vertical electrical sound- 


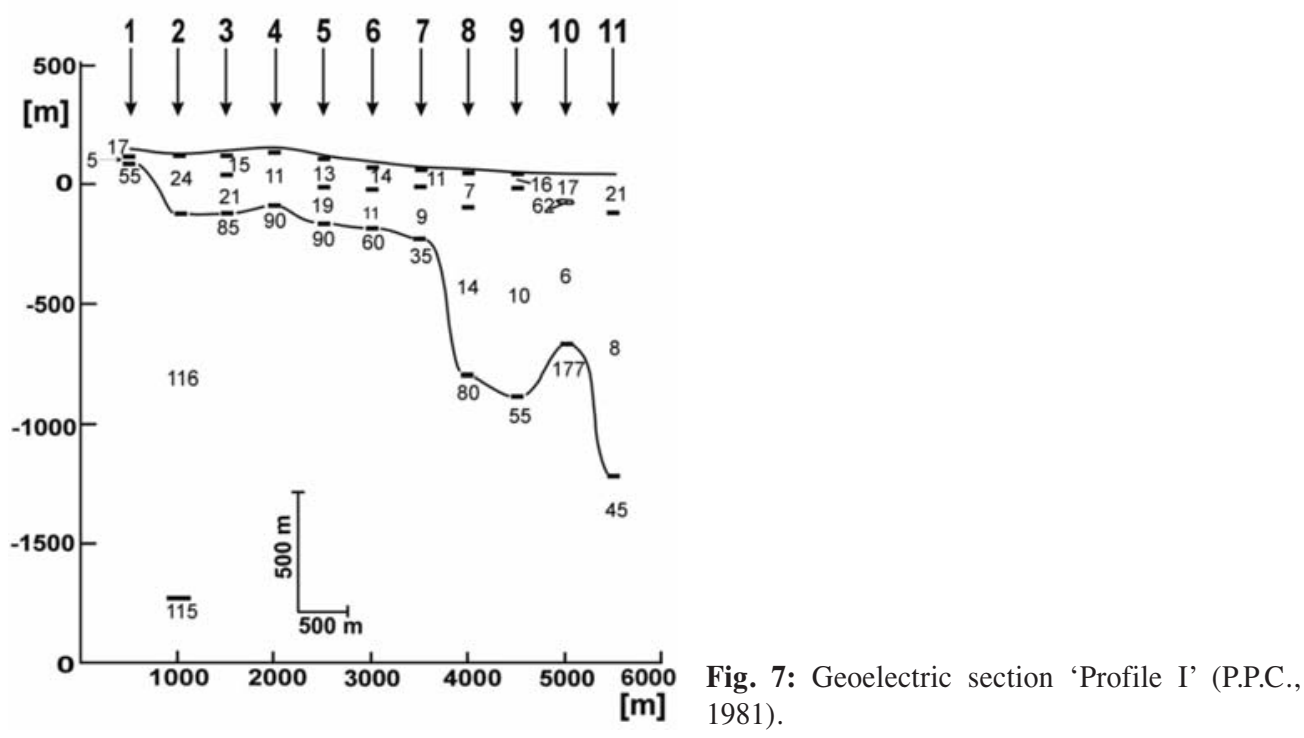

ings (V.E.S.) were performed using the Schlumberger array with current electrode spacing $\mathrm{AB} / 2=3,000 \mathrm{~m}$.

One of these geoelectric sections runs across the study area in a SW-NW direction. This resistivity section is characterized as 'Profile I' and its location is shown in Fig. 2. Fig. 7 illustrates the geoelectric section interpreted by Prof. J. Makris (P.P.C., 1981). Two geoelectric layers are distinguished in this cross-section. The upper layer is variable in thickness and has low resistivities ranging from 5 to $24 \Omega \mathrm{m}$. This layer corresponds to Neogene and Quaternary sediments of the area. The low resistivity values can be explained by reduced porosity and permeability due to the clayey composition of these sediments. It is confirmed by the comparison of the resistivity structure with data from irrigation and water supply wells close to some vertical electrical soundings. The lower geoelectric layer has relatively high resistivities ranging from 35 to $177 \Omega \mathrm{m}$ and corresponds to the basement. A large normal fault has been found between VES 7 and 8, in the village of Patriki. This fault has a throw of about $570 \mathrm{~m}$ and the basement deepens abruptly from 300 to $870 \mathrm{~m}$. Another large normal fault has been detected between VES 10 and 11 having a throw of about $560 \mathrm{~m}$ and the basement deepens northeastwards from 670 to $1230 \mathrm{~m}$ below sea level (bsl). A probable tectonic uplift of approximately 220 m occurs between VES 9 and 10, north of the village of Patriki. Finally, an important normal fault has been recognized between VES 1 and 2, in the area between the villages of Zervochori and Sitochori, having a throw of $210 \mathrm{~m}$. The deepening of the basement by $76 \mathrm{~m}$ between VES 4 and 5 can be explained by the probable presence of a normal fault there.

Geoelectrical surveys at shallow depths ( $<500 \mathrm{~m}$ deep) were carried out by I.G.M.E. (Nikolaidis and Theodoridis, 1986). These surveys comprised 30 Vertical Electrical Soundings (V.E.S.) arranged along 7 profiles (AT-1, AT-2, AT-3, AT-4, AT-6, AT-15 and AT-16). The locations of these profiles are shown in Fig. 2. All the vertical electrical soundings were made with the Schlumberger array. The main characteristic is the low resistivity values of the Quaternary and Pliocene sediments related to their clayey composition. Some probable and proven normal faults were identified on these profiles. Especially, a proven normal fault has been identified between VES 97 and VES 96 in profile AT-16. The position of this fault coincides with the location of the fault zone between CPD 270 and 


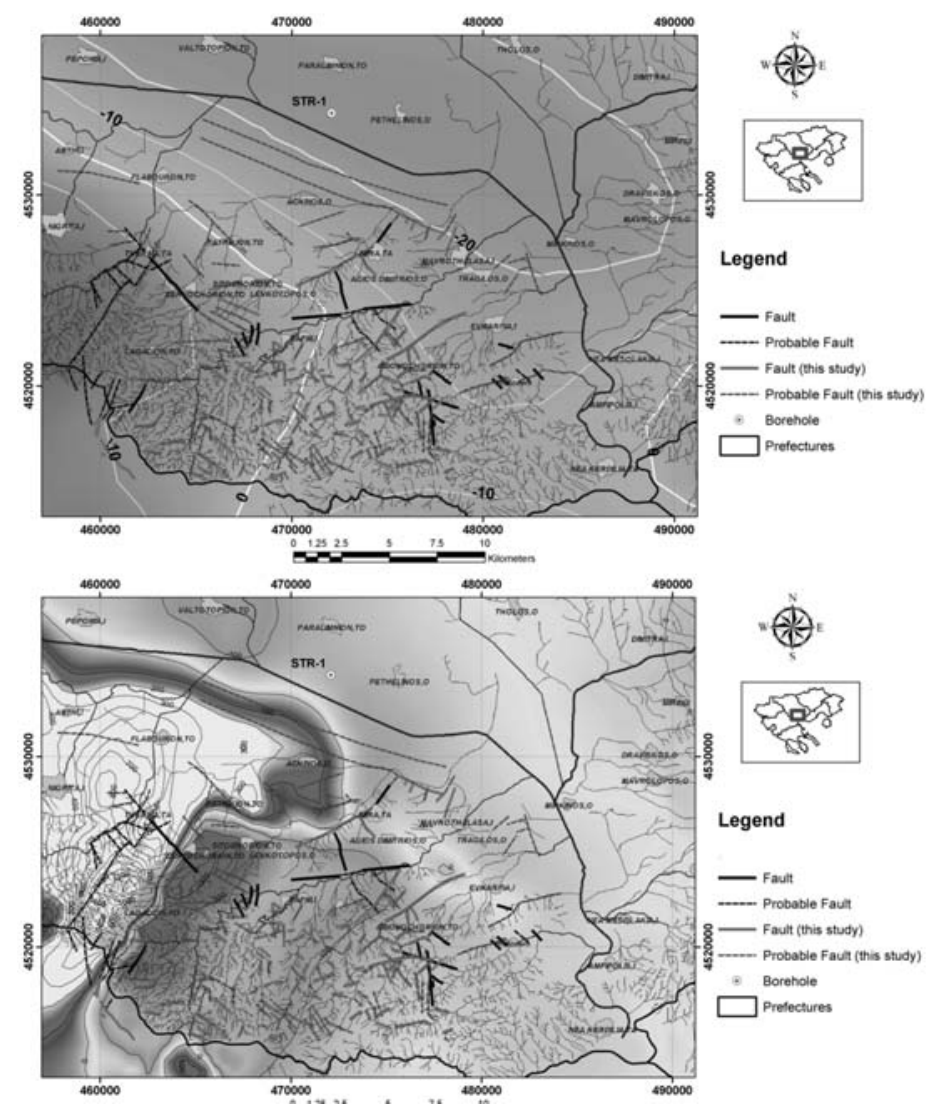

Fig. 8: Bouguer (top) and magnetic (bottom) anomaly maps in the SW part of the Strymon basin.

250 on seismic profile 'Line-7'. Probable normal faults have been detected at the following locations: (a) between VES 4 and 5 in profile AT-2, (b) close to VES 9 in profile AT-3, (c) between VES 36 and 37 in section AT-4 and (d) between VES 14 and 15 in profile AT-6. The probable faults detected in sections AT-3 and AT-4 coincide with the fault zone between CDP 350 and 320 of seismic profile 'Line-13'. In addition, the probable fault noted close to VES 37 in section AT-4 has been detected in the area of a terrace located at a distance of about $2 \mathrm{~km}$ east of the village of Tragilos.

\subsection{Gravimetric and magnetic methods}

The SW part of the Strymon basin was studied by means of regional scale gravity and magnetics. The Bouguer anomaly data used in this study were extracted from the public domain Greek gravity data bank (Lagios et al., 1988). The cell size of this data set was $4 \mathrm{~km}$. Positive gravity anomalies are observed over the metamorphic rocks of Serbomacedonian Massif, while negative anomalies are associated with the Strymon basin (Fig. 8). Aeromagnetic data from 1966 survey of Macedonia and Thrace were recompiled, processed (Stampolidis, 1999) and used in the present study to delineate the edges of the magnetized bodies in the area. Metamafic bodies are cropping out in the Serbomacedonian massif. The Therma proto-ophiolitic mafic rock assemblage is extended further under the basin sediments, as revealed from the magnetic data (Fig. 8). 


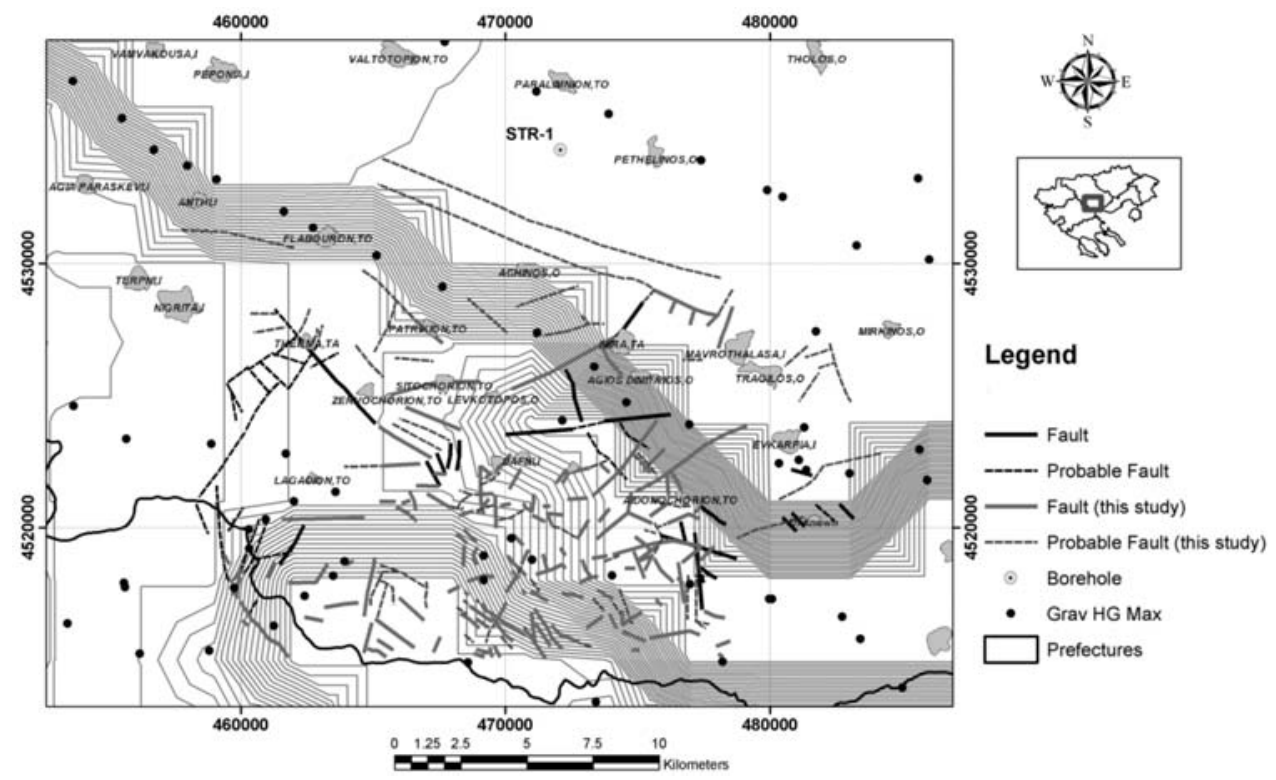

Fig. 9: Terracing of the Bouguer anomaly in a large part of the Strymon basin. The main faults of the basement in the SW part of the basin are noted.

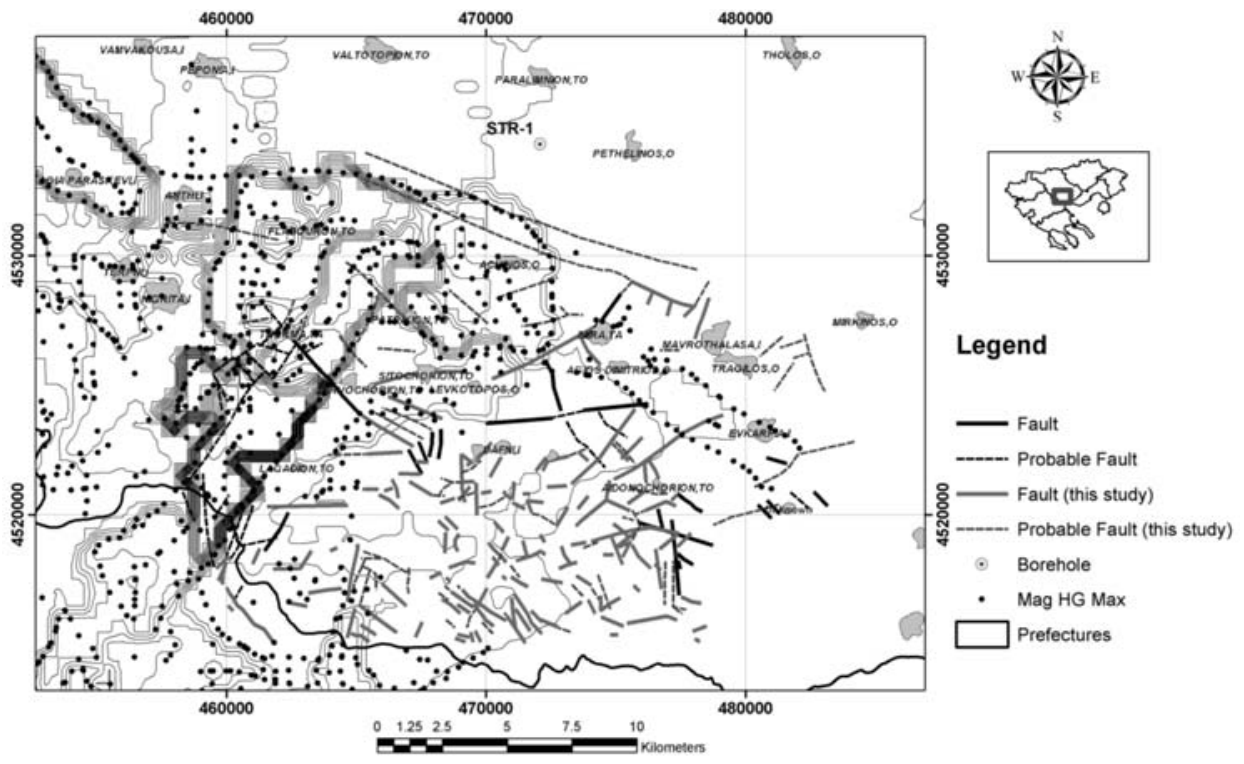

Fig. 10: Terracing of the magnetic anomaly in a large part of the Strymon basin. The main faults of the basement in the SW part of the basin are noted.

Horizontal gradient maxima were used to reveal the horizontal boundaries of the gravity and magnetic sources. According to Blakely and Simpson (1986) and Grauch and Cordell (1987) the maximum values of horizontal gradient will be located near vertical sides. Cordell and McCafferty (1989) 


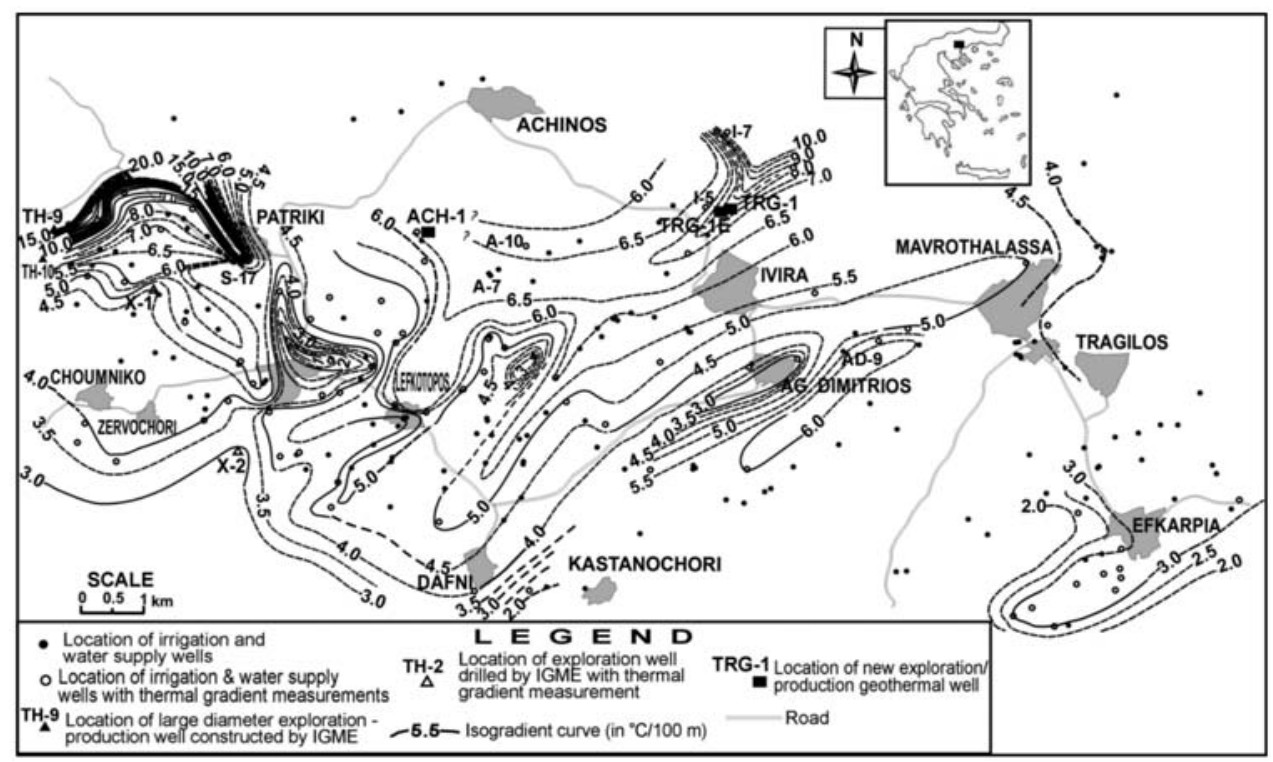

Fig. 11: Isogradient map (in oC/100 m) in the southwestern part of the Strymon basin based on the temperature measurements into existing irrigation and water supply wells (Arvanitis, 2003).

have presented an iterative method that they called "terracing" to transform the potential field data into uniform domains separated by abrupt domain boundaries. Terracing method used in conjunction with horizontal gradient maxima to delineate the body boundaries. The terracing of the Bouguer depicts the boundary between the metamorphic basement and the sediments of the basin (Fig. 9). This boundary is running parallel with the probable faults NE from Achinos that were recognized from the interpretation of the seismic profiles. The low resolution of the data set is the main reason for the insufficient details of the gravity boundaries. On the contrary the horizontal gradient maxima and terracing of the magnetic field (Fig. 10) evince more details for the magnetic bodies' boundaries. The exact position and the direction of the faults that were detected in this study near the Therma geothermal field coincide with the detected magnetic boundaries. A probable fault that was detected close to Patriki runs parallel to a terracing boundary. Southeast of Zervochori the HG Maxima align with a detected fault. The tectonic lines northeast of Achinos coincide with the northeast boundary of the concealed magnetic body and it is interpreted as a dispersed metamafic body similar to that outcropping in Therma.

\section{Geothermal situation in the area - Relationship with tectonic setting}

During preliminary geothermal investigation in the southwestern part of the Strymon basin a detailed thermometrical survey took place. All existing wells (about 230) for water supply and irrigation purposes were measured. In 80 boreholes up to depth of $300 \mathrm{~m}$ geothermal gradient measurements were possible. In most boreholes temperatures measured were constantly higher than the normal ones. For example, the temperatures of $37.7,34.6,28.6,34.2$ and $30.5^{\circ} \mathrm{C}$ were recorded at depths of 270,280,122, 300 and $235 \mathrm{~m}$ respectively in boreholes in the areas of Patriki, north of Ivira, south and southwest of Achinos. An isogradient map was drawn based on the measurements in irrigation and water supply wells (Fig. 11). The study area is characterized by an increased geot- 
hermal gradient, 2-3 times higher than the normal one. The isogradient curve corresponding to $3^{\circ} \mathrm{C} / 100 \mathrm{~m}$ delineates the area at the margins of the basin close to the crystalline basement. The geothermal gradient is higher with values as high as $10-15^{\circ} \mathrm{C} / 100 \mathrm{~m}$ in the western part of the study area near the known Therma - Nigrita low enthalpy geothermal field. Other significant thermal anomalies (geothermal gradient $>6^{\circ} \mathrm{C} / 100 \mathrm{~m}$ ) occur in the Patriki area, north of the village of Ivira and in the area between the villages of Patriki and Achinos. Geothermal interest manifests itself in the areas north of Mavrothalassa (gradient $>4^{\circ} \mathrm{C} / 100 \mathrm{~m}$ ), southwest of Ivira (Ivira - Dafni - Lefkotopos) and east of Agios Dimitrios. The isogradient map illustrates the correspondence between the geothermal data and the tectonic structure of the field. Furthermore, it appears that the main geothermal anomaly is associated with two NW-SE fault systems that affect the basement in the areas of Patriki and Achinos - Ivira respectively. The presence of NE-SW faults extends the anomaly southwestwards (Arvanitis, 2003). Faults intimately associated with geothermal anomalies in the study area have been detected by geophysical methods using mainly data from previous seismic and geoelectric surveys and their locations have been correlated positively with geomorphological features, the drainage pattern and lithology data from wells.

\section{References}

Arvanitis, A., 2003. Geothermal study in the SW part of the Strymon basin. PhD Thesis. Aristotle Univ. of Thessaloniki, Thessaloniki.

Blakely, R.J., and Simpson, R.W., 1986. Approximating edges of source bodies from magnetic or gravity anomalies. Geophysics, 51, 1494-1498.

Cordell, L., and McCafferty, A.E., 1989. A Terracing Operator for Physical Property Mapping with Potential Field Data. Geophysics, 54, 621-634.

Geosoft, 1997. OASIS Montaj Data Processing and Analysis (DPA) System for Earth Science Applications. Version 4.1 user Guide. Geosoft Inc., 290 pp.

Grauch, V.J.S., and Cordell, L., 1987. Limitations of determining density or magnetic boundaries from the horizontal gradient of gravity or pseudogravity data. Geophysics, 52, 118-121.

Lagios, E., Hipkin, R. G., Angelopoulos, A., and Nikolaou, S., 1988. The Gravity Anomaly Map of Greece - A Recompilation. I.G.M.E.

Nikolaidis, M. and Theodoridis, T., 1985. Geoelectrical investigation in the Strymon basin. Institute of Geology and Mineral Exploration (I.G.M.E.), 9 pp. + 12 figures and maps.

P.P.C. (Public Petroleum Corporation), 1988. Evaluation of deep holes, Athens, 42-53.

P.P.C. (Public Power Corporation), 1981. Geothermal Energy Project. Serres basin area. Geoelectrical survey. IfG (Prof. Dr J. Makris), Hambourg.

Stampolidis, A., 1999. The magnetic field of Macedonia and Thrace and its relation to the geological and geophysical structure of the area. PhD thesis, Aristotle Univ. of Thessaloniki. 